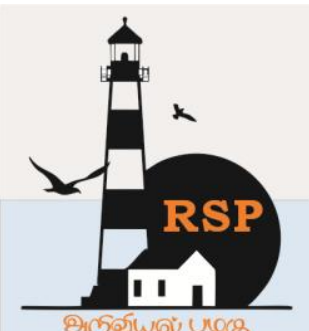

INTERNATIONAL RESEARCH JOURNAL ON ADVANCED SCIENCE HUB

Special Issue of First International Conference on Engineering, Science, and Technology (ICEST 2021)

\title{
A Study of Customer Preference and Attitude towards Online Shopping In Bihar
}

PriyankaKumari

Research Scholar, Department of Applied Economics and Commerce, Patna University, Patna

priyankakumari2009bhu@gmail.com

\begin{abstract}
Online marketing has gained huge popularity and importance all over the world. Considering the wide range of benefits it provides to marketers as well as customers, it has become one of the leading mediums of marketing. Both small as well as large-scale businesses gets opportunity to increase their sales in an effective way through online marketing. With the opportunities come the challenges also, which the marketers need to understand. The marketers need to figure out how they can use online marketing adequately for success of an organization. And something that is of paramount importance for successfully implementing online marketing is a good understanding of the customers. The marketer must know the demographic variables as well as choices of their target customers for making effective marketing strategies. Marketers ought to predict with utmost accuracy, the target customers buying preferences and their attitude on the basis of their demographic characteristics and also their buying intention. In this study attitude of customers of Bihar on the basis of their demographic variables like gender and age is determined. It is also tried to find out whether there is a relationship between attitude and buying intention of customers. Category of goods that consumers prefer to buy online in Bihar is also determined.
\end{abstract}

Key Words: Online Marketing, Demographic Variables, Marketing Strategies, Attitude Of Customers

\section{Introduction}

Online marketing has opened up new scope and dimensions of marketing. With enormous popularity, it has become an important medium of marketing in India and across world. Due to its cost effectiveness and ease of operation, new businesses are getting inclined to do its marketing in an online mode. To do online marketing effectively, understanding customer demography is of utmost importance. Before a business try to break into the market, an understanding of the nature of the market and the characteristics of population is crucial. The more understanding that an organization have about its customers, the better personalized offers it can make. This will result in increasing brand affinity and loyalty and thereby a higher return on investment for their marketing efforts.

\subsection{Purpose of the Study}

For the growth of an organization, it is very important that it gets more and more business. And for this it is very obvious that the marketer understands the population characteristics very well. Especially for a marketer who is trying to foray into a new business it's very important for him to understand the attitude of target customer based on their demography like gender and age and he should also be having an understanding of the type of good the customers prefer to buy online so as to take a correct decision regarding the category of goods he would be selling online.

\subsection{Objectives of the Study}

1) To analyze customer attitude towards online shopping on the basis of gender

2) To analyze customer attitude towards 
online shopping on the basis of age

3) To examine if there is any relationship between hours spent on Internet and attitude towards online shopping.

4) To examine if there is any relationship between customer attitude towards online shopping and Online shopping intention

5) To find out the category of goods customer prefer to buy online.

\section{Review of Literature}

- Divyendu, Siddharth Raj, Vivek Yadav (2019) Studied the preference of online and offline shopping based on multiple factors like geography, urgency of delivery and stage of development of countries.

- Ho Soo Fong 2013 state studied how various factors like demographic profile, perceived benefits and previous online shopping experience influences customer attitude

- Jozef Bucko, Lukáš Kakalejč́́k and Martina Ferencová (2018) in his paper examined the various factors that influence consumers willingness to do online shopping. The various criteria on the basis of which consumers make decisions while purchasing online was also evaluated.

- Ms. Supriya Mahajan, Ms. Neelakshi Saini (2018) made a comparison of customers perception towards online and offline shopping on the basis of demographic variables. Also the various factors that affect online and offline shopping was determined

- Rupali Rajesh (2018) in her study identified the various factors that influences online shopping behaiour of customers in Pune area and also examined the various democratic demographic factors that effects level of customer satisfaction.

\section{Research Design and Data Collection Method}

\subsection{Study Design}

This is a descriptive research as it will be describing the characteristics of the population and will not focus on why the pattern exists. Quantitative data collection method is used which include survey emphasizing objective measurements and numerical analysis of data collected.

\subsection{Data Collection}

Both primary as well as secondary data was used for the study. Initially secondary data was collected from journals, books, website and after that a well-structured closed-ended questionnaire was prepared. The questionnaire was divided into 3 sections .The first one relate to the demography of the respondents, second related to the attitude and shopping intentions of customers and the last section included questions based on their preference related to different category of goods.

\subsection{Sampling}

The survey was conducted in different cities of Bihar. Non-probability convenience sampling method was adopted and the samples were drawn from 120 respondents.

\subsection{Questionnaire Design}

5-point Semantic Differential Scale was used. It is a type of rating scale, which is used for psychological measurement. It is used for determining attitudes, approaches and the perspective of respondent.

\subsection{Data Analysis}

Hypotheses were formulated and tested statistically

$\mathbf{H}_{01}$ : There is no significant difference between attitude of male and female towards online shopping

$\mathrm{H}_{\mathrm{A} 1}$ : There is significant difference between attitude of male and female towards online shopping

\begin{tabular}{|c|}
\hline $\begin{array}{l}\text { Mann-whitney U Test result } \\
\text { The U-value is } 1239\end{array}$ \\
\hline $\begin{array}{l}\text { The Z-Score is } 2.9219 . \text { Critical value for a two- } \\
\text { tailed test is } z_{-} c=2.81 \text {, it is hence concluded } \\
\text { that the null hypothesis is rejected. }\end{array}$ \\
\hline $\begin{array}{l}\text { Using the P-value approach: The } \mathrm{p} \text {-value is } \mathrm{p}= \\
0.0034 \text {. The result is significant at } \mathrm{p}<.05 \text {. It is } \\
\text { concluded that the null hypothesis is rejected. }\end{array}$ \\
\hline $\begin{array}{l}\text { Therefore, there is enough evidence to claim that } \\
\text { the population median of differences is different } \\
\text { than } 0 \text {, at the } 0.05 \text { significance level. }\end{array}$ \\
\hline
\end{tabular}

Findings: Males have a better attitude towards online shopping than female 


\section{www.rspsciencehub.com}

$\mathbf{H}_{\mathbf{0 2}}$ :Age of customers does not have any significant relationship with attitude of customer towards online shopping

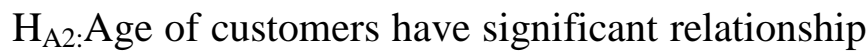
with attitude of customer towards online shopping

Age Group (1) Under 25

( 2) $25-44$

(3) 45 and above

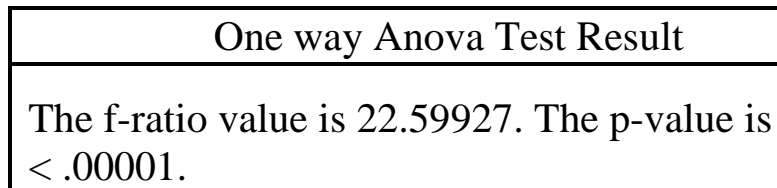

The result is significant at $\mathrm{p}<.05$.

\begin{tabular}{|c|c|c|c|}
\hline \multicolumn{4}{|c|}{ Post Hoc Tukey HSD (beta) } \\
\hline \multicolumn{2}{|c|}{$\begin{array}{c}\text { Pairwise } \\
\text { Comparisons }\end{array}$} & $\begin{array}{c}\text { HSD.05= } \\
0.2004\end{array}$ & Q.05=3.3572 \\
\hline \multirow{2}{*}{ T1:T2 } & $\mathrm{M} 1=3.81$ & 0.19 & $\begin{array}{c}\mathrm{Q}=3.17 \\
\mathrm{p}=.06851)\end{array}$ \\
\cline { 2 - 2 } & $\mathrm{M} 2=4.00$ & 0.36 & $\begin{array}{c}\mathbf{Q}=\mathbf{5 . 9 7} \\
(\mathrm{p}=.00014)\end{array}$ \\
\hline \multirow{2}{*}{ T1:T3 } & $\mathrm{M} 1=3.81$ & $\mathrm{M} 3=3.45$ & \begin{tabular}{c}
$\mathbf{Q}=\mathbf{9 . 1 4}$ \\
\cline { 2 - 2 } $\mathrm{p}=.00000)$
\end{tabular} \\
\hline T2:T3 & $\mathrm{M} 2=4.00$ & 0.55 & $\mathbf{d i f f e n c}$ \\
\hline
\end{tabular}

Findings: There is no significant difference between attitude of customer towards online shopping in the age group under 25 and 25 to 44 . The attitude of customer in the age group 45 and above is significantly different from the other two groups.

$\mathbf{H}_{\mathbf{0 3}}$ : There is no significant relationship between attitude of customers towards online shopping and hours spent on internet

$\mathrm{H}_{\mathrm{A} 3}$ : There is significant relationship between attitude of customers towards online shopping and hours spent on internet
(1) less than 1 hour a day
(2) 1 to 4 hours a day

(3) more than 4 hours a day

\begin{tabular}{|l|}
\hline \multicolumn{1}{|c|}{ One way Anova Test Result } \\
\hline $\begin{array}{l}\text { The f-ratio value is } 38.57593 . \text { The } \mathrm{p} \text {-value is } \\
<.00001 .\end{array}$ \\
\hline The result is significant at $\mathrm{p}<.05$ \\
\hline
\end{tabular}

Post Hoc Tukey HSD (beta)
Volume 03 Issue 01S January 2021

\begin{tabular}{|c|c|c|c|}
\hline \multicolumn{2}{|c|}{$\begin{array}{c}\text { Pairwise } \\
\text { Comparisons }\end{array}$} & $\begin{array}{c}\text { HSD. } 05= \\
0.2384\end{array}$ & $\begin{array}{l}\text { Q.05 = } \\
3.3572\end{array}$ \\
\hline \multirow[b]{2}{*}{$\mathrm{T} 1: \mathrm{T} 2$} & $\mathrm{M} 1=3.00$ & \multirow[b]{2}{*}{0.63} & \multirow{2}{*}{$\begin{array}{c}Q= \\
8.80(p= \\
.00000)\end{array}$} \\
\hline & $\mathrm{M} 2=3.63$ & & \\
\hline \multirow[b]{2}{*}{ T1:T3 } & $\mathrm{M} 1=3.00$ & \multirow[b]{2}{*}{0.91} & \multirow{2}{*}{$\begin{array}{c}Q= \\
12.79(p= \\
.00000)\end{array}$} \\
\hline & $\mathrm{M}_{3}=3.91$ & & \\
\hline \multirow[b]{2}{*}{$\mathrm{T} 2: \mathrm{T} 3$} & $\mathrm{M} 2=3.63$ & \multirow[b]{2}{*}{0.28} & \multirow{2}{*}{$\begin{array}{c}Q= \\
3.98(p= \\
.01559)\end{array}$} \\
\hline & $\mathrm{M}_{3}=3.91$ & & \\
\hline
\end{tabular}

Findings: There is significant difference between attitudes of customer towards online shopping based on the hours they spend on internet. The customers who spent more hours on internet have a better attitude towards online shopping.

$\mathbf{H}_{04}$ : There is no significant relationship between attitude of customers towards online shopping and Online shopping intention

$\mathrm{H}_{\mathrm{A} 4}$ : There is significant relationship between attitude of customers towards online shopping and Online shopping intention

Spearman's correlation coefficient

The value of rs is: 0.71721 .

Findings: This indicates a strong positive relationship between the attitude of customers towards online shopping and Online shopping intention.

Category Of Goods Consumer Prefer To Buy Online

\begin{tabular}{|c|c|c|}
\hline \multicolumn{3}{|c|}{ a) clothing } \\
\hline \multicolumn{3}{|c|}{ Frequency Distribution Table } \\
\hline Class & Count & Percentage \\
\hline $\begin{array}{l}\text { Not at all } \\
\text { preferred }\end{array}$ & 4 & 3.3 \\
\hline Not preferred & 18 & 15 \\
\hline Undecided & 29 & 24.2 \\
\hline Preferred & 64 & 53.3 \\
\hline Highly preferred & 5 & 4.2 \\
\hline Total & 120 & 100 \\
\hline \multicolumn{3}{|c|}{ b)Beauty and health product } \\
\hline \multicolumn{3}{|c|}{ Frequency Distribution Table } \\
\hline Class & Count & Percentage \\
\hline
\end{tabular}


www.rspsciencehub.com

\begin{tabular}{|c|c|c|}
\hline $\begin{array}{l}\text { Not at all } \\
\text { preferred }\end{array}$ & 4 & 3.3 \\
\hline Not preferred & 19 & 15.8 \\
\hline Undecided & 2 & 1.7 \\
\hline Preferred & 65 & 54.2 \\
\hline Highly preferred & 30 & 25 \\
\hline Total & 120 & 100 \\
\hline \multicolumn{3}{|c|}{ c)Kitchen items } \\
\hline \multicolumn{3}{|c|}{ Frequency Distribution Table } \\
\hline Class & Count & Percentage \\
\hline $\begin{array}{l}\text { Not at all } \\
\text { preferred }\end{array}$ & 18 & 15 \\
\hline Not preferred & 4 & 3.3 \\
\hline Undecided & 20 & 16.7 \\
\hline Preferred & 42 & 35 \\
\hline Highly preferred & 36 & 30 \\
\hline Total & 120 & 100 \\
\hline \multicolumn{3}{|c|}{ d)Electronic Appliances } \\
\hline \multicolumn{3}{|c|}{ Frequency Distribution Table } \\
\hline Class & Count & Percentage \\
\hline $\begin{array}{l}\text { Not at all } \\
\text { preferred }\end{array}$ & 5 & 4.2 \\
\hline Not preferred & 30 & 25 \\
\hline Undecided & 12 & 10 \\
\hline Preferred & 7 & 5.8 \\
\hline Highly preferred & 66 & 55 \\
\hline Total & 120 & 100 \\
\hline \multicolumn{3}{|c|}{ e)Footwear } \\
\hline \multicolumn{3}{|c|}{ Frequency Distribution Table } \\
\hline Class & Count & Percentage \\
\hline $\begin{array}{l}\text { Not at all } \\
\text { preferred }\end{array}$ & 4 & 3.3 \\
\hline Not preferred & 65 & 54.2 \\
\hline Undecided & 24 & 20 \\
\hline Preferred & 7 & 5.8 \\
\hline Highly preferred & 20 & 16.7 \\
\hline Total & 120 & 100 \\
\hline \multicolumn{3}{|c|}{ f)Home Decor } \\
\hline \multicolumn{3}{|c|}{ Frequency Distribution Table } \\
\hline Class & Count & Percentage \\
\hline $\begin{array}{l}\text { Not at all } \\
\text { preferred }\end{array}$ & 3 & 2.5 \\
\hline Not preferred & 3 & 2.5 \\
\hline Undecided & 3 & 2.5 \\
\hline
\end{tabular}

Volume 03 Issue 01S January 2021

\begin{tabular}{|c|c|c|}
\hline Preferred & 31 & 25.8 \\
\hline Highly preferred & 80 & 66.7 \\
\hline Total & 120 & 100 \\
\hline \multicolumn{3}{|c|}{ g) Furnitures } \\
\hline \multicolumn{3}{|c|}{ Frequency Distribution Table } \\
\hline Class & Count & Percentage \\
\hline $\begin{array}{l}\text { Not at all } \\
\text { preferred }\end{array}$ & 7 & 5.8 \\
\hline Not preferred & 50 & 41.7 \\
\hline Undecided & 43 & 35.8 \\
\hline Preferred & 5 & 4.2 \\
\hline Highly preferred & 15 & 12.5 \\
\hline Total & 120 & 100 \\
\hline \multicolumn{3}{|c|}{ h)Sports and fitness } \\
\hline \multicolumn{3}{|c|}{ Frequency Distribution Table } \\
\hline Class & Count & Percentage \\
\hline $\begin{array}{l}\text { Not at all } \\
\text { preferred }\end{array}$ & 6 & 5 \\
\hline Not preferred & 27 & 22.5 \\
\hline Undecided & 24 & 20 \\
\hline Preferred & 33 & 27.5 \\
\hline Highly preferred & 30 & 25 \\
\hline Total & 120 & 100 \\
\hline
\end{tabular}

Findings: Strong preference for online shopping of clothing, beauty and health products, kitchen items, electronic appliances and home décor goods is observed.

\section{Conclusion}

It can be concluded that there is a significant effect of customer age and gender in online shopping. Younger generation and those who spend more time on internet are more keen to shop online as they are more well versed in using technology. It is also observed that customers from male group are more interested in online shopping than females. The study revealed that attitude and intention are strongly and positively correlated .Marketers should consider these population characteristics while deciding their marketing plans to get a competitive advantage over their competitors.

\section{References:}

[1].PoonamChahal. A Study on the Role of Consumers Gender and Age on Online Shopping. (International Journal in Commerce, IT \& Social Sciences Vol.2 Issue-07, July, 2015)

[2].Shweta Gupta, EktaBansal . Consumer Orientation Towards Online Buying Via Social 
Media Platforms (IJSRE Volume 4 Issue 1 January 2016)

[3].Dr.ArchanaAgrawal, ShreyanshTiwari, Dr.C.V.Raman. A study on factor affecting eshopping behavior of customer with special referencetobilaspur city (International Journal of Management, IT \& Engineering Vol. 6 Issue 12, December 2016)

[4].Rahul ArghaSen . Online Shopping: A Study of the Factors Influencing Online Purchase of Products in Kolkata (International Journal of Management and Commerce Innovations Vol. 2, Issue 1, Month: April 2014 -September 2014)

[5].AchalHardia and KapilSharma . Empirical Study of Factors Affecting Online Shopping Amongst Youths (Global Journal of Management and Business Studies. Volume 3, Number 2 (2013)

[6].Mohammad AnisurRahman, Md. Aminul Islam, BushraHumyraEsha, Nahida Sultana \&SujanChakravorty . Consumer buying behavior towards online shopping: An empirical study on Dhaka city, Bangladesh (Rahman et al., Cogent Business \& Management (2018) 